\title{
Measuring and Analyzing the Impact of GDP on Consumer Spending in Iraq for the Period 1990- 2018
}

\author{
Prof. Salah Mahdi Abbas Al-Birmani, Assist Lecturer: Abdullah Muhammad Rashid Al-Ramli \\ Faculty of Administration and Economics, Baghdad University
}

DOI: $10.37648 /$ ijrssh.v10i04.027

Received:08 ${ }^{\text {th }}$ November, 2020; Accepted:30 ${ }^{\text {th }}$ November, 2020; Published: 04th December, 2020

\begin{abstract}
Consumption is one of the topics that occupies a wide field in economic research, due to the importance it represents in economic activity as it is one of the most important components of aggregate demand, because the largest percentage of individuals 'incomes is directed to consumption, and therefore it would drive growth and move economic activity towards prosperity, therefore This research attempts to measure the function of household consumption spending in the Iraqi economy during the period from 1990-2018 using the ARDL model. The results of this study have shown that there is a long-term balance relationship between income and family consumption spending and that consumer spending depends heavily on income and there is a direct relationship between Consumer spending and income has a marginal propensity to consume $0.519 \%$

Keywords: Consumption, the theories explaining the function of consumption, GDP.
\end{abstract}

\section{INTRODUCTION}

Family consumption spending in any country is one of the important indicators that have received focus in economic studies due to the importance of this variable on the level of economic activity on the one hand, and its impact on macroeconomic variables on the other hand, as family consumption spending is the main pillar in building various policies Economic conditions in developed and developing countries, Iraq has witnessed major changes and transformations in the pattern of family consumption spending during the period (19902018) as a result of the economic conditions that Iraq went through during this period, and the importance of such standard models of family consumption spending in determining consumer behavior and the extent of their influence With various economic factors, especially since the Iraqi economy was known for many economic problems, including economic sanctions in 1990 and the ban on oil exports, which directly affected the source of family income, which led to a decrease in purchasing power, and then the war and regime change in 2003 and the accompanying destruction of the infrastructure and the process stopped Productivity, security and political instability.

Research problem: Despite the improvement in income, the Iraqi citizen still has not satisfied many of his basic and essential needs.

Research hypothesis: The marginal propensity to consume per Iraqi person is high, because he has not satisfied many of his basic needs.

The importance of the research: The importance of the research comes through the interest in the family consumption function in determining the form of the 
relationship between the economic variables studied in the Iraqi economy in knowing the behavior of consumers, as the Iraqi consumer depends in his spending method on the size of the income he gets.

\section{search limits:}

Spatial Frontiers: The Iraqi Economy.

Temporal boundaries: 1990-2018.

Research method: The research combines the descriptive and analytical method in presenting the economic facts contained in the research, as well as the quantitative method in building standard models.

Research structure: The research was divided into three sections. The first topic dealt with the conceptual framework of the consumption function and theories explaining the consumer spending function and the gross domestic product. The second topic analyzed the development of consumer spending and the gross domestic product in the Iraqi economy during the research period, while the third topic dealt with estimating and analyzing the relationship Between consumption and GDP.

\section{THE FIRST TOPIC: THE CONCEPTUAL FRAMEWORK FOR THE SIGNIFICANCE OF CONSUMER SPENDING AND GDP.}

\section{First: Consumer Spending}

Consumer spending is one of the components of aggregate demand, and "consumer spending" is defined as spending on goods and services used to meet the needs and desires of individuals during a certain period, which is usually a year $(5,2008$ Andolfatto), as for that part of disposable income that is not used in the purchase of goods Consumption, so it is called saving, (Al-Kuraiti, 2018, 208).

Consumer spending depends on many factors, including income, interest rates, the general level of prices, the size of the population, the structure of the national income distribution among members of society and the size of wealth, as well as tastes that play a role in consumer demand and affect it either negatively or positively, but income is the main determinant. Consumption, and there is a positive relationship between consumption and income, meaning that if total income rises, total consumption will rise accordingly, and the opposite may be true, and we express that mathematically as follows: (Sakhry, 2005, 55).

Taxes play a role in influencing individual consumption spending through their effect on disposable income, and that any increase in tax rates reduces disposable income, which makes them reduce their consumption and vice versa, and that expectations also have an important role in influencing the behavior of individuals, both in relation to In price or availability of goods, and thus this will be reflected in the level of consumption. (Raid, 2016, 11).

\section{Second: Theories explaining the consumer spending function.}

Income is one of the most important determinants of the level of consumption. Therefore, we find that most theories focused on their interpretation of the determining factors of consumption expenditure on income, and the most important of these theories are the following: -

solute Income Hypothesis: The theory of treasure in consumption is often called the theory of absolute income in order to emphasize that consumption decisions are based on the absolute amount of current income that individuals have, that is, consumption is at the absolute and current level of income, that is, that:

$\mathrm{C}=f(\mathrm{yd}) \ldots \ldots \ldots \ldots 1$

Where $\mathrm{C}$ represents current consumption, while $\mathrm{Yd}$ represents disposable income (personal income after tax), this means that the basic relationship between consumption and income is the short-run consumption function, which is the consumption function that Keynes arrived at:

$\mathrm{C}=0+1 \mathrm{Yd} \ldots 2$

Consumption for Keynes depends on two factors: the average propensity to consume (APC) and income, and the increase in consumption associated with a certain increase in income depends on the marginal propensity to consume. (Average, 105, 2017).

This means that the change in consumption is either due to the change in income with the stability of the tendency to consumption, or to the change in the 
propensity to consume with the stability of income and it is known that the tendency to consumption depends on two types of factors: subjective factors and objective factors. (Darwish, 136, 2019).

Kinz noticed that subjective factors do not change except in the long run, and thus he considered them fixed and thus the propensity to consume changes in the short run with the influence of objective factors only, and hence Keynes concluded that the propensity to consume is almost constant in the short run, meaning that the proportion of what society allocates to consumption from current income is constant. Or current.

In light of this, consumption changes in the short term depend on changes in income not on changes in the propensity to consume, so current income is generally considered the main change that determines consumption in the short period. Another assumption for Wickens is that consumption increases as income increases, but the increase in consumption is less. From the increase in income, for this reason Keynes assumed that the average propensity to consume decreases as income increases.

\section{The Relative Income Hypothesis.}

In 1949, the economist Deisenberg presented his theory on consumption and the extent of its correlation with the level of relative income, meaning that the relationship between consumption and income is a relative relationship, and then he extracted a new form of the consumption function in the long period that differs from the Keynesian consumption function in the short period. This study is based on two important assumptions. (Saqr, 89, 1983)

The first assumption: that consumption depends on relative income (relative to the income of other individuals) or their consumption, and relative to previous income or previous consumption, and simply that consumption does not depend on absolute income but on relative income, that is, that the family's spending depends on the spending of other families that Live next door to that family, and this is called the phenomenon of (simulation), which means that families are affected by the surroundings or neighbors, so that low or middle income families, if they live in the middle or relatively rich neighbors, will lead this family to imitate or emulate the neighbors, even if the need to spend income Even if the income is not sufficient or little, these families can resort to borrowing or other means in order not to diminish their social value.

The second assumption: Deisenberg believes that what Keynes assumed that the relationship between income and consumption is always identical is a wrong and unrealistic assumption, as the relationship between consumption and income is not always the same over a certain period of time, so Duesenberg has introduced what is known as economic fluctuations or cycles, saying that if it increased Income will increase consumption and this is agreed upon, but if income reaches its highest level and there is a fluctuation or economic cycle and income decreases, consumption will not decrease, and the reason is that consumers will maintain the same levels of consumption they were accustomed to before the economic cycle. Therefore, he believes that consumption does not depend on the disposable income in this period only, but also on the highest income obtained in a previous period. (Darwish, 137, 2019).

\section{The Permanent Income Hypothesis.}

In the framework of permanent income assumption developed by Friedman, current consumption under the permanent income theory depends on the current income and expected income in the future. For example, if the family expects that its income will increase in the coming period, it is possible that this family will consume more than what its current income level indicates. Friedman's theory is based on three basic assumptions: (Makhlif, 116, 2017).

The first hypothesis: that the actual income (Y) of the family and its consumption in a certain period of time is divided into two components: permanent and transitional. Permanent income (YP) according to Friedman is that part of the current income that is characterized by continuity and stability (such as salary and monthly increment), i.e. it is The amount of income a family can spend without compromising its wealth. Wealth means the present value of the income the family is expected to receive in the future.

As for transitional income (YT), it may be interpreted as unexpected income (such as incentive rewards, gifts, aid, etc.) and it is either positive or negative. 
(IJRSSH) 2020, Vol. No. 10, Issue No. IV, Oct-Dec

According to Friedman:

$\mathbf{Y}=\mathbf{Y P}+\mathbf{Y T} \ldots \ldots . .3$

$\mathrm{C}=\mathrm{CP}+\mathrm{CT}$

That is, income is divided into two parts, permanent and transitional, and the actual consumption of the family is also divided into two components: permanent consumption and transitional consumption, which is interpreted as unexpected consumption (such as an unexpected doctor's bill or a gift for a specific occasion, etc.).

The second hypothesis: Friedman assumed that permanent consumption is a fixed proportion of permanent income, so he says that:

$\mathrm{CP}=\mathrm{K} . \mathrm{YP} \ldots \ldots .5$

Where $\mathrm{K}$ is a ratio whose value ranges between zero and the correct one and says that consumption represents a fixed proportion of income that does not change but $\mathrm{K}$ itself depends on other factors represented in the interest rate, the level of taste and habits, and the ratio of human wealth to material wealth.

The third assumption: Friedman assumed that there is no relationship between permanent income and transitional income, because any fluctuations in income do not affect permanent income but rather a sudden process that quickly ends, as he assumed that there is no relationship between permanent consumption and transitional consumption, meaning that: MPC = Zero ... (Saqr, 93, 1983).

\section{The Life Cycle Hypothesis}

This theory appeared in 1950 and was finalized in 1963. This theory was called MBA after the first letter of each of the names of the three economists: Modigliani, Bromberg and Ando.

This theory is based on the assumption that the consumer lives for a number of years $\mathrm{T}$ and has primary wealth $\mathrm{W}$ and gets income $\mathrm{Y}$ during the period $\mathrm{R}$, and that he is looking for a level of consumption that he maintains throughout his life. Follows:

$C=(W+R y) T \ldots \ldots 6$

This theory holds that in the short run, wealth is constant, and therefore the consumption function of the
e-ISSN: 2249-4642, p-ISSN: 2454-4671

life cycle theory is similar to the Keynesian consumption function, but in the long run and with rising wealth, the consumption function shifts upward and the average propensity to consume does not decrease with the rise in income, thus Modigliani was able to solve the consumption problem Caused by the difference in the average propensity to consume between the short run and the long run. (Al-Khatib, 82, 2014)

\section{Third: Gross Domestic Product:}

It represents the sum of the final values of goods and services of various kinds that are produced in a particular country during a certain period of time, usually a year, as the gross domestic product is a geographical or regional concept related to the productive activities that take place within the political borders of that country regardless of who owns these productive services Whether they are citizens or foreigners. * ((Gregory, 2004,502), and accordingly, no good or service that is produced outside the country is included in the gross domestic product.

\section{THE SECOND TOPIC: ANALYZING THE REALITY OF HOUSEHOLD CONSUMPTION SPENDING AND GROSS DOMESTIC PRODUCT IN IRAQ}

First: Analysis of the development of the gross domestic product.

The gross domestic product is one of the indicators expressing the level of the state's economic performance, and that the analysis of the growth of output and the structuring of the sectors is one of the main points to find out the places of imbalance and to address them. From 1990 to the present time.

We notice from Table (1) a fluctuation in the value of the gross domestic product during the study period, as the level of the gross domestic product reached (55926.5) million dinars in 1990, to fall to its lowest level in 1991 to reach (42451.6) million dinars, with a negative annual growth rate of (24.09-) This deterioration in the gross domestic product is due to the outbreak of the first Gulf War and the entry of Iraqi forces into Kuwaiti lands. The effects of this war were reflected in the destruction of the infrastructure, the factories and factories ceasing production, the cessation of a large part of oil exports, the decrease in investment, 
and with the end of the war and the return of life to Its nature, the gross domestic product rose again, to witness a qualitative improvement to $(115,108.4$ million dinars $)$ at an annual growth rate (171.1) in 1992, due to the increase in public sector production and the Iraqi government support during that period for the industrial and agricultural sector, with the aim of directing agricultural production To the local sector to finance the ration card items, and with the intensification of the economic sanctions imposed by the United Nations, which resulted in a decline in industrial and agricultural production and a deterioration in the performance of the current sectors And other services, which led to the deterioration of the value of the gross domestic product in Iraq, to reach (6500924.6) million dinars in 1996 with a negative annual growth rate of (-2.9), and then it increased again after the signing of the memorandum of understanding with the United Nations in 1997 which Including the oil-for-food and medicine program to reach (50213699.9) million dinars in 2000, with an annual growth rate of $(45.6 \%)$, but this increase did not last long until the decline in 2002, and the compound growth rate was $(160.3 \%)$ as well as the average annual growth rate $(101.2 \%)$. For the period 1990-2002, the reason for the decline is due to the decline in global demand for oil after the events of September 2001.

As for the period (2003-2018), the beginning of this period witnessed fundamental changes in all aspects of economic activity as a result of the change in the system of government in (2003), as the gross domestic product (GDP) took an increasing path, except for some years because it was characterized by exceptional circumstances, as the gross domestic product increased Significantly from previous years, where the output increased from (29585788.6) million dinars in 2003 to (53235358.7) million dinars in 2004 with an annual growth rate of $79.9 \%$ due to the openness of the Iraqi economy to the outside world as a result of the lifting of economic sanctions and the increase in the export of Iraqi oil significantly, which contributed to The increase in the gross domestic product, the increase in the strength of the Iraqi dinar and the increase in the exchange rate against foreign currencies, then the GDP continued to rise gradually and in varying proportions until it reached (157026061.6) million dinars, with an annual growth rate of $(40.8 \%)$. Oil, in addition to the increase in crude oil revenues as a result of the increase in exported quantities and the increase in oil prices, as well as the relative improvement in the security situation, which affected significantly It responds to achieving a kind of recovery for the Iraqi economic sectors, and then back to decline in 2009 due to the repercussions of the global crisis that occurred in 2008 and its reflection on the global demand for oil. Therefore, oil prices decreased and the exported quantities decreased, which led to a decline in the rate of growth of the gross domestic product, which reached (130643200.4) (One million dinars in 2009, at a negative annual growth rate ($16.8 \%$ ), after which it rose again due to the end of the global crisis, the increase in global demand for oil, the rise in oil prices and the improvement in the security situation, and the gross domestic product reached its highest level in 2013, reaching (273587529.2)) One million dinars, with a growth rate of $(7.6 \%)$, but this increase did not last long until it returned to decline again in $(2014,2015)$ if it witnessed a tangible decline and negative growth rates if these rates reached $(-2.6 \%)$ ($26.9 \%)$. The reason for this decline is due to the repercussions of the security situation that Iraq witnessed at the beginning of 2014, which was represented by the entry of ISIS and the control of some areas, as well as the sharp decline in oil prices and consequently the deterioration of oil revenues, after which the result returned to the gradual rise of It reached (251064479.9) million dinars in 2018 with a positive annual growth rate of $(11.2 \%)$, as a result of the tangible improvement in the security situation, the elimination of ISIS criminal gangs and the liberation of the usurped cities of Iraq, which in turn worked to increase oil exports, as well as the rise in oil prices during that period This led to an increase in the gross domestic product, and the compound growth rate reached $(15.3 \%)$ and the average annual growth rate (16.7\%) for the period 2003-2018. 
(IJRSSH) 2020, Vol. No. 10, Issue No. IV, Oct-Dec

e-ISSN: 2249-4642, p-ISSN: 2454-4671

$\begin{array}{lllllllll}\text { Figure (1): } & \text { (The trend of the GDP trend at current prices in Iraq }\end{array}$

300000000
250000000
200000000
150000000
100000000

Figure 1 prepared by the researcher based on the data of Table (1).

Source:

Figure (1) shows the development path of the gross domestic product for the period of the study (1990-2018), as it was at its highest level in 2013, reaching (273587529.2) million dinars, and the reason for this is the rise in global oil prices at this stage, the increase in exports, and the improvement of the situation. Security, which in turn was reflected in the increase in oil revenues, while it was at its lowest level in 1991, reaching (42451.6) million dinars, which is very low due to the blockade that Iraq was subjected to in the nineties of the last century, and the decline in oil revenues as a result of stopping oil exports after the war In the second Gulf region, the compound growth rate reached (35.03\%) and the average annual growth rate (54.5\%) for the period studied (1990-2018).

\section{Second: Analyzing the reality of consumer spending in Iraq:}

The total family consumption expenditures reached its highest level in 2018 as it reached (115034381.7) million dinars, and the lowest level was in 1990 if it reached (25295) million dinars, as we note through Table (1) that the annual growth rate of consumer spending was It is increasing at an equal rate for a period of four years from 1990 to 1994, at an annual growth rate of $58.2 \%$, which is a high rate. This increase was due to high levels of inflation, and this increase continued until 1994 and at high growth rates due to the escalation of inflation waves due to the economic sanctions on Iraq, which began in August (1990), and the consequent imposition of economic and military sanctions, represented by preventing the export of Iraqi oil, and the consequent decline in the levels of GDP, as it relies on oil as a major commodity for its revenues to cover the growing war expenses and to cover The deficit in its budget due to military spending resulting from the impact of the Gulf War, and spending during this period was limited to the contents of the ration card, and this period was marked by the onset of hyperinflation, and then consumer spending decreased in 1996 with a growth rate A negative (14.0\%) and after the signing of the Memorandum of Understanding and a decrease in price levels, after which consumer spending returned to the increase with a growth rate of $(93.7 \%)$ and this increase continued with different growth rates until it reached (22.6\%) in 2002, and the compound growth rate reached Consumer spending for the period (19902002) reached (64.5\%), and the compound growth rate is considered high because it is spending at current prices and not fixed, meaning that inflationary effects are not excluded from it, as well as the expansion of the monetary issuance process at that time due to economic sanctions, and the average growth rate is Annual consumer spending $(99.45 \%)$ for the period 1990-2002, that these conditions were behind the decline in the value of the Iraqi dinar as a result of inflationary financing of the deficit, which was the cause of the continuous rise in the prices of goods and services, in addition to that private consumption spending is affected by a number of behavioral factors that are not technical or Engineering that can be 
changed or controlled, such as customs, traditions, high prices, expectations, and many influencing factors, both positive and negative, all of these factors were the cause of fluctuating levels of consumer spending, but after (2003) a Family consumption spending has an increasing trend, with the exception of some years because it was characterized by exceptional circumstances and due to the rentier nature of public revenues, as the total family consumption expenditures increased significantly, as family consumption expenditures reached (13616500.9) million dinars in 2003, due to the increase in the level of income due to the payment of salaries State employees in hard currency dollars (the dollarization phenomenon), (Hassoun, 1999, 128), and then consumer spending continued as a result of high oil revenues, as the rise in oil revenues indirectly affects private consumption spending by raising employees' incomes and indirectly also through Investment, as for the direct impact, is through government spending. Consumer spending has continued to rise until it reached (72026324.0) million dinars in 2010 with an annual growth rate of $(5.5 \%)$, after which it rose to a growth rate of (7.5\%) in 2011, but the total Family consumption spending has been declining in its growth rates for the period 2014-2018, the reason for that is the state of recession that the Iraqi economy has experienced due to the drop in oil prices and the entry of ISIS, etc. The increase in prices was reflected in the decrease in investment spending, and this caused a decrease in income levels in the private sector and a decrease in government spending in general, and the compound growth rate reached (15.28\%), as well as the average annual growth rate of $15.9 \%$ for the period 2003-2018, and the following figure shows the path of spending development Family consumption for the period 1990-2018.

Figure No. (2) shows the development path of consumer spending, as it was at its highest level in 2018, reaching (115034381.7) million dinars, and the reason for this is the rise in global oil prices at this stage and the increase in exports, which was reflected in the increase in salaries and grants provided by the government For individuals, while it was at its lowest level in 1990, reaching (25295.0) million dinars, which is very low due to the economic sanctions that Iraq was subjected to in the days of the nineties of the last century, the compound growth rate was (35.1\%) as well as the average annual growth rate (57.7\%). ) For the period 1990-2018.

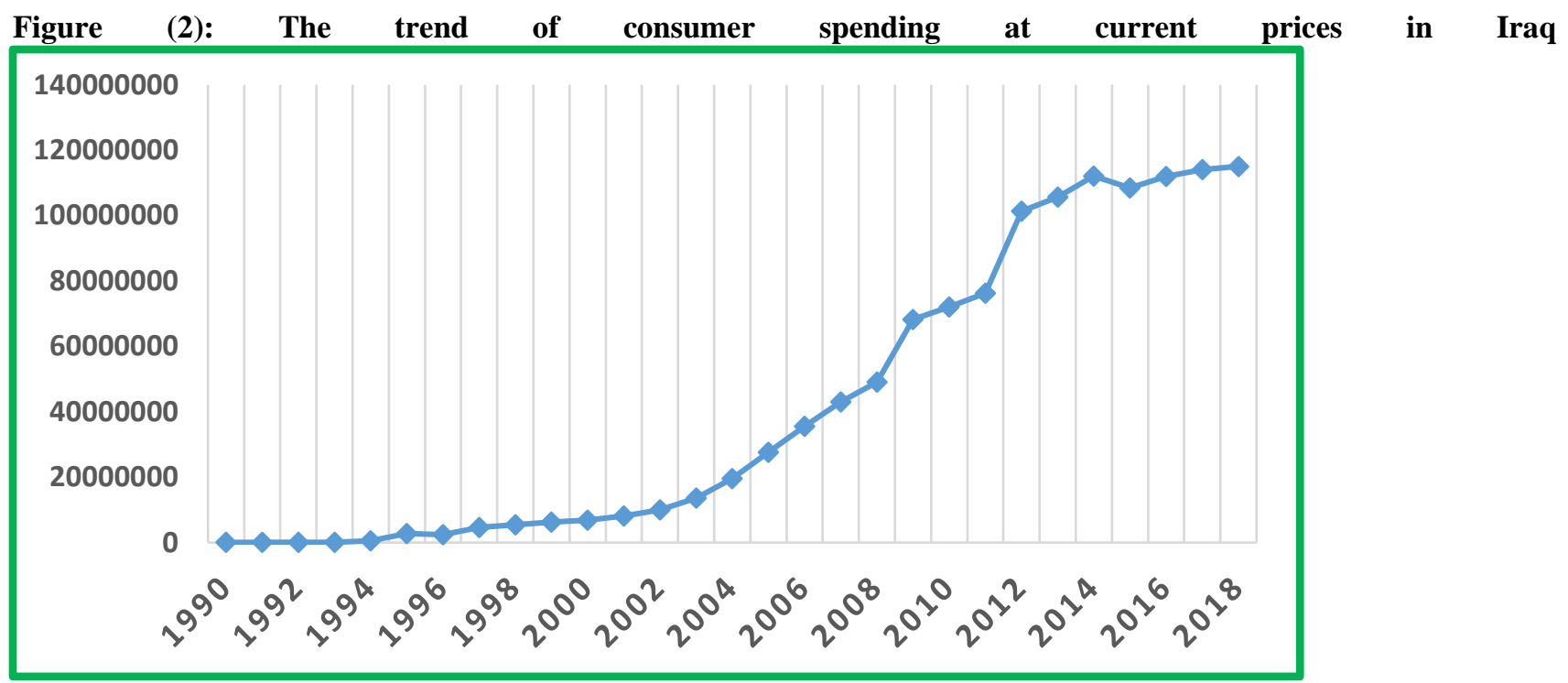

Source: the figure prepared by the researcher based on Table (1). 


\begin{tabular}{|c|c|c|c|c|c|c|c|c|}
\hline $\begin{array}{l}\text { Compound } \\
\text { growth\% }\end{array}$ & $\begin{array}{l}\text { Average } \\
\text { growth } \\
\text { rate } \%\end{array}$ & $\begin{array}{l}\text { Annual } \\
\text { growth } \\
\text { rate } \%\end{array}$ & $\begin{array}{l}\text { Consumer } \\
\text { spending * }\end{array}$ & $\begin{array}{l}\text { Compou } \\
\text { nd } \\
\text { growth } \\
\%\end{array}$ & $\begin{array}{l}\text { Average } \\
\text { growth } \\
\text { rate\% }\end{array}$ & $\begin{array}{l}\text { Annual } \\
\text { growth } \\
\text { rate\% }\end{array}$ & $\begin{array}{l}\text { Gross domestic } \\
\text { product } \%\end{array}$ & Years \\
\hline 8 & 7 & 6 & 5 & 4 & 3 & 2 & 1 & \\
\hline \multirow{13}{*}{64.5} & \multirow{13}{*}{99.45} & -- & 25295.0 & \multirow{13}{*}{160.3} & \multirow{13}{*}{101.2} & - & 55926.5 & 1990 \\
\hline & & 58.2 & 40026.3 & & & -24.09 & 42451.6 & 1991 \\
\hline & & 58.2 & 63339.2 & & & 171.1 & 115108.4 & 1992 \\
\hline & & 58.2 & 100234.0 & & & 179.4 & 321646.9 & 1993 \\
\hline & & 462 & 563758.0 & & & 415.5 & 1658325.8 & 1994 \\
\hline & & 393.9 & 2784330.0 & & & 303.7 & 6695482.9 & 1995 \\
\hline & & -14.0 & 2394361.0 & & & -2.9 & 6500924.6 & 1996 \\
\hline & & 93.7 & 4637831.3 & & & 132.1 & 15093144.0 & 1997 \\
\hline & & 17.6 & 5451845.4 & & & 13.4 & 17125847.5 & 1998 \\
\hline & & 15.5 & 6297974.6 & & & 101.2 & 34464012.6 & 1999 \\
\hline & & 8 & 6799171.8 & & & 45.6 & 50213699.9 & 2000 \\
\hline & & 19.5 & 8123672.1 & & & $\begin{array}{ll}-17.7 \\
\end{array}$ & 41314568.5 & 2001 \\
\hline & & 22.6 & 9956626.5 & & & -0.7 & 41022927.4 & 2002 \\
\hline \multirow{16}{*}{15.2} & \multirow{16}{*}{15.9} & 36.8 & 13616500.9 & \multirow{16}{*}{15.3} & \multirow{16}{*}{16.7} & 27.9- & 29585788.6 & 2003 \\
\hline & & 43.5 & 19538773.0 & & & 79.9 & 53235358.7 & 2004 \\
\hline & & 41.2 & 27593239.7 & & & 38.1 & 73533598.6 & 2005 \\
\hline & & 28.8 & 35526339.7 & & & 29.9 & 95587954.8 & 2006 \\
\hline & & 20.9 & 42963013.3 & & & 16.6 & 111455813.4 & 2007 \\
\hline & & 14.3 & 49091355.7 & & & 40.8 & 157026061.6 & 2008 \\
\hline & & 39.0 & 68256193.2 & & & -16.8 & 130643200.4 & 2009 \\
\hline & & 5.5 & 72026324.0 & & & 24.05 & 162064565.5 & 2010 \\
\hline & & 7.5 & 76260346.7 & & & 34.09 & 217327107.40 & 2011 \\
\hline & & 32.8 & 101299565.5 & & & 16.9 & 254225490.7 & 2012 \\
\hline & & 4.1 & 105696745.4 & & & 7.6 & 273587529.2 & 2013 \\
\hline & & 5.9 & 112036294.4 & & & -2.6 & 266332655.1 & 2014 \\
\hline & & -3.2 & 108396524.9 & & & -26.9 & $\mathbf{1 9 4 6 8 0 9 7 1 . 8}$ & 2015 \\
\hline & & 3.3 & 111917984.4 & & & 1.1 & 196924141.7 & 2016 \\
\hline & & 1.9 & 114058380.6 & & & 14.6 & 225722375.5 & 2017 \\
\hline & & 0.86 & 115034381.7 & & & 11.2 & 251064479.9 & 2018 \\
\hline \multicolumn{2}{|l|}{35.1} & \multicolumn{3}{|c|}{$\begin{array}{l}\text { Compound growth rate for the period } \\
1990-2018\end{array}$} & 35.0 & \multicolumn{3}{|c|}{$\begin{array}{l}\text { Compound growth rate for the period } \\
1990-2018\end{array}$} \\
\hline \multicolumn{2}{|l|}{57.7} & \multicolumn{3}{|c|}{$\begin{array}{l}\text { Average annual growth rate for the } \\
\text { period 1990-2018 }\end{array}$} & 54.5 & \multicolumn{3}{|c|}{$\begin{array}{l}\text { Average annual growth rate for the } \\
\text { period } 1990-2018\end{array}$} \\
\hline
\end{tabular}

Source: Table (1) prepared by the researcher based on:

- *Republic of Iraq, Ministry of Planning, Government Investment Programs Department, Investment Budget Division for the years 1990-2018. 
THE THIRD TOPIC: ASSESSMENT AND ANALYSIS OF THE RELATIONSHIP BETWEEN CONSUMPTION AND GDP.

First: the stability of the time series.

We notice through Table (2) that the results of both tests are similar and did not stabilize from the level (Level), but stabilized at the first (1) 1 difference with a significant level (5\%) and only at the fixed boundary (Intercept) for all variables, and from here we must reject the hypothesis Nothingness $(\mathrm{H} 0=0)$ and accept the alternative hypothesis $(\mathrm{H} 1=1)$, as in the following table.

Table (2): Results of time series stability test

\begin{tabular}{|c|c|c|c|c|c|c|}
\hline \multicolumn{7}{|c|}{ Extended Dickey-Fuller test results } \\
\hline \multirow[t]{2}{*}{ Variables } & \multicolumn{3}{|l|}{ Level } & \multicolumn{3}{|c|}{$1^{\text {st }}$ Difference } \\
\hline & ADF & Sig. & Result & ADF & Sig. & Result \\
\hline $\mathbf{Y}$ & -0.099615 & 0.9402 & No stationary & -3.987087 & 0.0050 & stationary \\
\hline C & 1.043488 & 0.9959 & No stationary & -4.083213 & 0.0040 & stationary \\
\hline \multicolumn{7}{|c|}{ Philips Piron test results } \\
\hline \multirow[t]{2}{*}{ Variables } & \multicolumn{3}{|l|}{ Level } & \multicolumn{3}{|c|}{ 1st Difference } \\
\hline & $\mathbf{P P}$ & Sig. & Result & $\mathbf{P P}$ & Sig. & Result \\
\hline $\mathbf{Y}$ & 0.047095 & 0.9554 & No stationary & -3.964193 & 0.0053 & stationary \\
\hline $\mathbf{C}$ & 0.603469 & 0.9872 & No stationary & -4.053537 & 0.0043 & stationary \\
\hline
\end{tabular}

Source: The table was prepared by the researcher using (10Eviews) program.

Second: The ARDL Self-Regression Model Test.

After testing the dormancy of time series for economic variables (GDP) as an independent variable, and consumption as a dependent variable, and it was found that all of them were stable at the first point I (1) and with this condition we were able to apply the test of the ARDL model and the table below shows us the test results for this model.

Table (3): Results of the ARDL model for consumer spending

\begin{tabular}{|c|c|c|c|c|c|}
\hline Variable & \multicolumn{2}{|c|}{ Coefficient } & \multicolumn{2}{|c|}{ t-Statistic } & Prob*. \\
\hline C1(-1) & \multicolumn{2}{|c|}{0.752625} & \multicolumn{2}{|c|}{11.19515} & 0.0000 \\
\hline $\mathbf{Y}$ & \multicolumn{2}{|l|}{0.128634} & \multicolumn{2}{|l|}{4.282980} & 0.0002 \\
\hline C & 516885.1 & \begin{tabular}{l|l}
1310771 \\
\end{tabular} & \multicolumn{2}{|l|}{0.394337} & 0.6967 \\
\hline $\begin{array}{l}\text { Adjusted } \\
\text { squared }\end{array}$ & 0.989717 & Durbin-Watson stat & 2.527862 & $\begin{array}{l}\text { Prob(F- } \\
\text { statistic) }\end{array}$ & 0.00000 \\
\hline
\end{tabular}

Source: Table of researcher numbers based on Eviews.10 program output.

Table (3) shows us that the ARDL model automatically determines the degrees of time slowdown for the two variables $(\mathrm{C} 1, \mathrm{Y})$, since the degree of slowing down of the dependent variable $(\mathrm{C} 1)$ was one degree, while the independent variable ((Y) does not have a time delay period, and results have shown Adjusted R- Squared (AR-S) news that income Y as an independent variable has explained $(98 \%)$ of the changes occurring in the dependent variable $(\mathrm{C} 1)$, and that $(0.2 \%)$ is due to other factors not included in the model, in other words that $(98 \%)$ is the ability of the independent variable (Y) to predict the dependent variable $\mathrm{C} 1$. As for the (F-statistic) test at a probability level (.0000Prob0.), Less than (5\%), it indicates the 
overall significance of the model statistically and indicates the statistics of D-W Which reached its peak (2.128716) and this explains that the model is free from the problem of self-correlation.

\section{Third: Results of the Bound Test:}

The Bound Test is used to find out the extent of the existence of a long-term equilibrium relationship (the existence of covariance) between (gross domestic product) as an independent variable and (consumption) as a dependent variable, by comparing the F statistic with the limits of the upper and lower critical values, as in the following table: -

Table (4): Results of the Bound Test for the consumer spending model

\begin{tabular}{|l|l|l|}
\hline Test Statistic & Value \\
\hline F-statistic & 14.35839 & 1 \\
\hline (Critical Value Bound) & I0 Bound & I1 Bound \\
\hline \multicolumn{2}{|l|}{} & 3.51 \\
\hline $10 \%$ & 3.02 & 4.16 \\
\hline $5 \%$ & 3.62 & 4.79 \\
\hline $2.5 \%$ & 4.18 & 5.85 \\
\hline $1 \%$ & 4.94 & K
\end{tabular}

Source: Table: From the researcher's numbers, depending on the output of Eviews.10.

We notice from table (4) above that the calculated value (F-statistic) amounted to 14.35839), which is greater than the maximum and minimum tabular value as it reached (4.16), (3.62) at a significant level (5\%), which means that we reject the null hypothesis We accept the alternative hypothesis, which means the existence of a joint complementarity relationship between consumer spending and gross domestic product, meaning a long-term equilibrium relationship.

Fourth: Testing the estimated parameters (short term) and the unrestricted error correction factor.

This test illustrates the estimation of the short-term parameters in order to reveal the degree of influence of the independent variable on the dependent variable, as well as determining the type of short-term relationship, and the error correction factor also shows the speed of returning in the long term to equilibrium, and the table below explains that.

Table (5): Results of estimating the error-correcting model and the short-term relationship of the consumer spending model

\begin{tabular}{|l|l|l|l|l|}
\hline \multicolumn{2}{|c|}{ Variable } & \multicolumn{1}{c|}{ Std. Error } & t-Statistic & Prob*. \\
\hline \multicolumn{1}{|c|}{ Y } & \multicolumn{1}{c|}{$\mathbf{0 . 1 2 8 6 3 4}$} & $\mathbf{0 . 0 3 0 0 3 4}$ & $\mathbf{4 . 2 8 2 9 8 0}$ & $\mathbf{0 . 0 0 0 2}$ \\
\hline C & $\mathbf{5 1 6 8 8 5 . 1}$ & $\mathbf{1 3 1 0 7 7 1}$ & $\mathbf{0 . 0 0 0 0 0 0}$ & $\mathbf{0 . 0 0 0 0}$ \\
\hline CointEq(-1)* & $\mathbf{0 . 2 4 7 3 7 5}-$ & $\mathbf{0 . 0 3 6 2 6 9}$ & $\mathbf{- 6 . 8 2 0 6 4 5}$ & $\mathbf{0 . 0 0 0 0}$ \\
\hline
\end{tabular}

Source: Table of researcher numbers based on Eviews.10 program output.

We notice through Table (5) the results of estimating the parameters of the independent variable in the short term, as the table shows the positive relationship between (1C) and (Y) i.e. when increasing income (Y) by one unit leads to an increase in consumption $(\mathrm{C} 1)$ by $(0.128)$ Unit at a significant level $(0.0002$ Prob $=)$ with other factors remaining constant, and this is consistent with the logic of economic theory, and that the amount $(0.128)$ represents the marginal propensity to consume (and this figure decreases due to the use of GDP data and not per capita disposable income). 
The estimated relationship also showed that the unrestricted error correction coefficient (UECM) reached a value of ($0.24)$ negative and significant with probability $(0.0000=$ Prob $)$, and this reflects the existence of a balanced relationship in the short term between the studied variables towards a long-term equilibrium relationship, and the value of the error correction factor Means that $(24 \%)$ of the imbalance (short-term imbalance) in $(\mathrm{C} 1)$ in the previous period ( $\mathrm{t}-1)$ can be corrected with the current period $((\mathrm{t})$ towards the long-term equilibrium relationship due to any shock or change in the variable Independent, meaning that consumption takes about (4) years towards the equilibrium value due to any shock in the model or change in the independent variable.

Fifth: testing the estimated parameters (long-term).

This test demonstrates the estimation of the long-term parameters in order to reveal the degree of influence of the independent variable on the dependent variable, as well as determine the type of long-term relationship, as in the following table:

Table (6): Results of estimating long-term parameters of the consumer spending model

Table of researcher numbers based on Eviews.10 program output.

Levels Equation
Case 2: Restricted Constant and No Trend
\begin{tabular}{|l|l|l|l|l|}
\hline Variable & Coefficient & Std. Error & t-Statistic & Prob* $^{*}$ \\
\hline Y & $\mathbf{0 . 5 1 9 9 9 8}$ & $\mathbf{0 . 0 4 4 5 4 6}$ & $\mathbf{1 1 . 6 7 3 4 0}$ & $\mathbf{0 . 0 0 0 0}$ \\
\hline C & $\mathbf{2 0 8 9 4 8 1 .}$ & $\mathbf{5 4 6 5 2 0 9}$. & $\mathbf{0 . 3 8 2 3 2 4}$ & $\mathbf{0 . 7 0 5 5}$ \\
\hline
\end{tabular}

Table (6) shows us the results of estimating the long-term parameters, as the table shows that there is a direct relationship between (Y) and (1C) i.e. when increasing (Y) by one unit leads to an increase of (C1) by (0.519) units, while the factors remain. The other is fixed, and at a level of significance (Prob $=0.0000$ ), and this is very logical in economic terms, the higher the income the higher the consumption, as (0.519) represents the marginal propensity to consume and it is very high if compared to the short term (0.12), and the reason for this The large increase in consumer spending is the result of an increase in effective aggregate demand due to the payment of state employees 'salaries in hard currency dollars (the dollarization phenomenon) after 2003, and then consumer spending continued to rise gradually as a result of the high oil revenues on which the Iraqi economy depends on a large percentage in financing its current expenditures. Increase employees 'salaries and increase spending on government services. Consumer spending has continued to rise until the end of the study period.

Previously, by estimating the short-term parameters in Table (5) that there is a direct relationship between consumption and gross domestic product, where the parameters of the dependent variable (C1) indicated that it did not exceed (0.12), meaning that the positive relationship in the short term will continue in the long term That is, the more income leads to an increase in consumption, and this is consistent with economic theory.

Sixthly: Conducting diagnostic tests for the estimated residues.

For the purpose of making sure of the validity and accuracy of the results obtained in the previous tests, we will conduct some important diagnostic tests to prove this as follows: - 
1-Serial Correlation LM Test: This test is used to ascertain the extent to which the estimated model is free from the problem of self-correlation of residues, as follows: -

Table (7): Results of the LM self-correlation problem test for the government spending model

$\mid$\begin{tabular}{l|l|l|l|}
\hline Breusch-Godfrey Serial Correlation LM Test: \\
\hline F-statistic & $\mathbf{1 . 7 9 1 8 3 8}$ & Prob .F(2,23) & $\mathbf{0 . 1 8 9 1}$ \\
\hline Obs*R-squared & $\mathbf{3 . 7 7 4 6 0 7}$ & Prob. Chi-Square(2) & $\mathbf{0 . 1 5 1 5}$ \\
\hline
\end{tabular}

Source: Table: From the numbers of the researcher based on the output of Eviews.10.

Table (7) shows us the results of the autocorrelation problem test, as we note that the value of (F-statistic) at a probability level reached $(0.1891 \mathrm{Prob}=)$ and it is greater $(5 \%)$ and this means that there is no self-correlation problem, and then here we must accept The null hypothesis, which states that there is no correlation problem between random residues, and we reject the alternative hypothesis that states that there is a correlation problem between random residues, and then this test enhances the accuracy of the ARDL model results.

2-The Heteroskedasticity Test (ARCH): This test is used to ascertain the extent to which the estimated model is free from the variance problem of the residuals as shown below: -

Table (8): Results of the ARCH variance problem test for the consumer spending model

\begin{tabular}{|l|l|l|l|}
\hline \multicolumn{2}{|l|}{ Heteroskedasticity Test: ARCH } \\
\hline F-statistic & $\mathbf{0 . 1 4 8 4 8 2}$ & Prob .F(1,25) & $\mathbf{0 . 7 0 3 2}$ \\
\hline Obs*R-squared & $\mathbf{0 . 1 5 9 4 1 4}$ & Prob. Chi-Square(1) & $\mathbf{0 . 6 8 9 7}$ \\
\hline
\end{tabular}

Table: From the researcher's numbers based on Eviews.10 program output.

Table (8) shows us the results of testing the variance difference problem for ARCH, as we note that the value of (Fstatistic) at a probability level reached $($ Prob $=0.7032)$ and it is greater $(5 \%)$. This means that the model is devoid of the problem of variance, and then this test enhances the accuracy of the results of the model ARDL.

3-Structural Stability Test Models. The estimated ARDL structural stability test is an important test in order to ensure that the data used in the study are free from the presence of any structural changes in it, as in the following figure: 
Figure (3)

Results of stability test of the estimated model of a consumption function

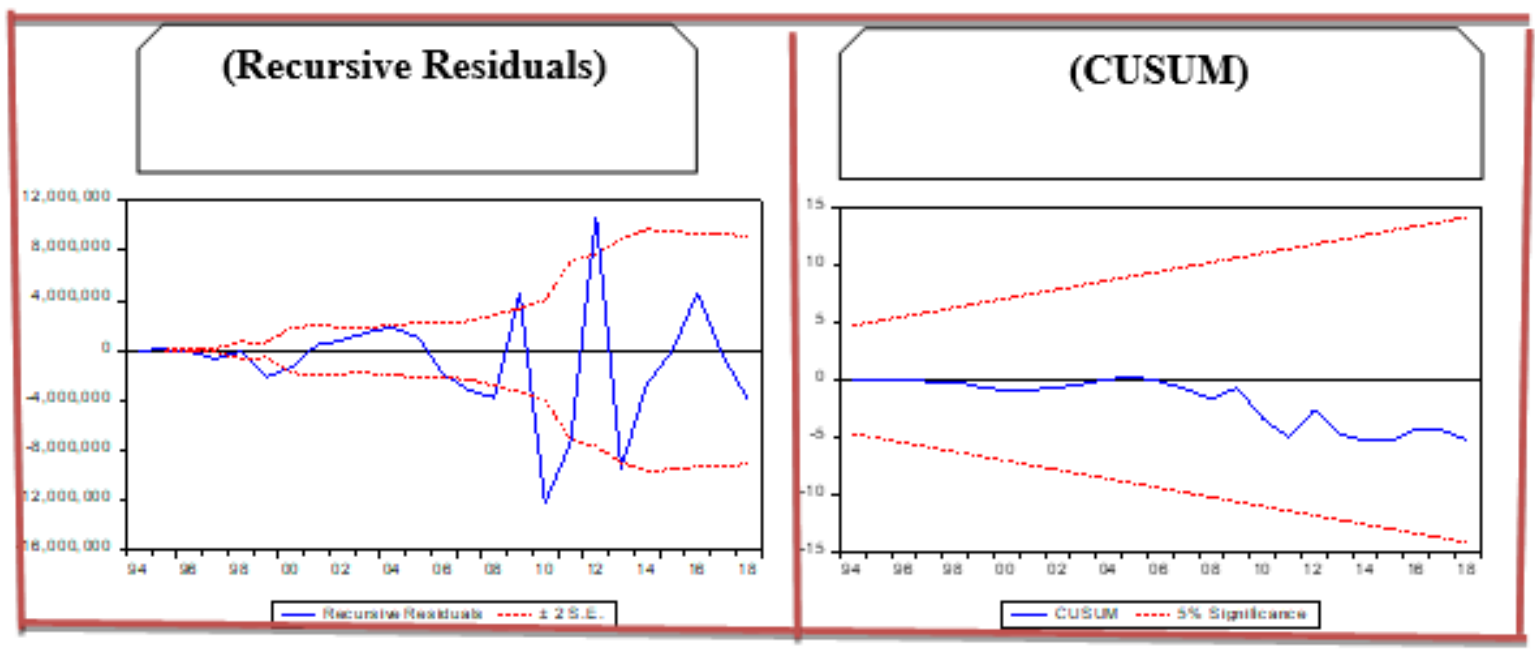

\section{Source: Figure from the researcher's numbers based on Eviews.10 program output.}

We note from Figure (3) and from the CUSUM section) that the cumulative sum of the remainder within the boundaries of critical values at a significant level $(5 \%)$, and this indicates the stability of the estimated model in the short and long term, while the Recursive Residuals test shows movement and fluctuation around the medium. The value of zero) is within the boundaries of critical values at a level of significance (5\%). It is evident from the two tests that there is stability and harmony in the model between long-term results and short-term results between consumption and GDP.

\section{CONCLUSIONS \& RECOMMENDATIONS}

\section{First: Conclusions:}

1- The dependence of the family consumption spending sector in Iraq mainly on gross domestic product (income).

2- The marginal propensity to consume was 0.52 , which is a low percentage that does not reflect the reality of the Iraqi economy, for the use of GDP data and not personal disposable income.

3- The standard unit root test showed that the independent variable (GDP) and the dependent variable (consumption expenditure) remained at the first difference.
4- The results of the Bounds Test revealed to us that there is a common complementarity and long-term equilibrium relationship between GDP and household consumption spending.

5- The long-term estimated parameters revealed to us that the relationship between the independent variable (output) and the dependent variable (consumption expenditure) is mutually exclusive, and this is consistent with the logic of economic theory.

6- The ARDL model showed that the signals of the short-term parameters were positive at significant probability values, which explains the direct effect of household consumption spending on GDP in the short term.

7- The results of the diagnostic tests confirmed that the results of the ARDL model are realistic and can be reliably relied upon.

\section{Second: Recommendations:}

1- The necessity of planning consumer spending for the purpose of satisfying basic and luxury needs and allocating part of the national income for the purpose of investment, especially infrastructure projects. 
(IJRSSH) 2020, Vol. No. 10, Issue No. IV, Oct-Dec

2- The Ministry of Planning and the Central Bureau of Statistics to prepare studies on consumer spending in the Iraqi economy.

3- Imposing progressive taxes on unnecessary consumer goods, in order to reduce consumer spending.

\section{SOURCES}

\section{First: Arab Sources:}

1 -Abd Juman, Michael, Macroeconomics Theoretical and Politics, Translation and Arabization: Muhammad Ibrahim Mansour, Mars House for Publishing and Distribution, Riyadh, 1988.

2 -Hassoun, Subhi, The phenomenon of dollarization in the Iraqi economy, Journal of Economic Studies, Issue 3, First year, House of Wisdom, Baghdad, 1999.

3 -Khalil, Sami, Macroeconomic Theory: Basic Concepts and Theories, Al-Ahram Distribution Agency, Cairo, $1994,628$.

4-Darwish, Hussain Dukan, Hussain, Atyaf Hussam, Estimation and Analysis of the Depreciation Function in the Iraqi Economy According to the "Moon" Model of External Temporal Backwardness for the Period (1997-2012)، Journal of the College of Administration and Economics for Economic, Administrative and Financial Studies, Volume 9, Issue 2, 2017.

5-Raid, Hassan Kalif, The relationship between the components of aggregate demand and income distribution in Iraq for the period (1990-2014), PhD thesis, College of Administration and Economics, University of Baghdad, 2016.

6- Sakhry, Omar, Macroeconomic Analysis, Fifth Edition, University Press Office, Algeria, 2005.

7-Saqr, Ahmad Saqr, Macroeconomic Theory, Second Edition, Publications Agency, Kuwait, 1983.

8-Al-Kuraity, Talib Hussain, Al-Ruwaishdi, Ali Kaddouri, The Impact of Governmental Expenditure on Private Expenditure in Iraq, Journal of Administration and Economics, Karbala University, Vol.

9-Mikhlif, Asma, Estimation of the consumption function in Algeria for the period 1990-2015, Journal of Industrial Economics, Issue 13, 2017.

10-Maaleh, Haloub Kazim, Macroeconomics, First Edition, New Amal House for Printing and Publishing, Damascus, Syria, 2017.

\section{Second: Annual Reports:}

1 -Republic of Iraq, Ministry of Planning, Government Investment Programs Department, Investment Budget Division, for the years 1990-2018.

\section{Third: Foreign Sources:}

1- 1N. Gregory Mankiw, Professor of Economics, Harvard University Publisher: South, Western ,2004. 